\title{
MORAL VALUES IN ANDREA HIRATA'S NOVEL AYAH
}

\author{
Kandri, Jumino Suhadi, M. Manugeren \\ Master's Program, Fakultas Sastra, \\ Universitas Islam Sumatera Utara, Medan, Indonesia \\ Corresponding author: kandriarisaalgayoniy1@gmail.com
}

\begin{abstract}
The research deals with moral values. Moral values are the standards of good and evil, which govern an individual's behavior and choices. Individual's morals may derive from society and government, religion, or self. When moral values derive from society and government they, of necessity, may change as the laws and morals of the society change. (Harris, 2012). There are two points of moral values analyzed in the novel. The first is hard work and the second is self-confidence and both are depicted through the words and actions of the major characters. Hard work is the key to success. Hard work always pays off. Hard work can turn sludge into gold. Hard work starts from where people stop looking for alternatives. (Tollander, 2011); the second is self-confidence, a belief in one's own ability when doing anything, by viewing things positively and realistically (Albert, 2010). The research is conducted by descriptive qualitative method proposed by Creswell (2010). The results show that there are two points of moral values in the novel. The first is hard work and the second is self-confidence and both of the points are described by the major characters.
\end{abstract}

Key words: moral values, hard work, self-confidence

\section{Introduction}

Andrea Hirata's novel Ayah was published in May 2015. He exposes his friend's story because he thinks that this story is worth reading and gives a deep impression of the roles of a father. The novel is themed with friendship having some priceless elements of moral values and the setting is mostly taken in Belitong Island, Indonesia. The novel Ayah tells the life of Sabari who strongly pursues his love for Marlena, though Sabari has to experience bitterness in matters of romance. Sabari as the name goes is always patient, leading his life with confidence and hard work. Sabari is not alone; he is always accompanied by his friends Ukun, Tamat, Toharun, and some others. The story deepens the reader's feelings with the dramatic poems presented in the novel.

The plot in this story uses a mixed groove. Hirata starts this story with Sabari's situation that has collapsed as he is left behind by his wife. The whole story is then reestablished to show how all the events could happen and then continued to the solutions of matters. On another perspective, the author uses a third-person point of view. The author also uses some other names which are adjusted to the proper situation and time. 
Formerly, among all our friends here, Sabari is the one who is always late in all matters. He is the one who could finally read the holy verses after all his friends are already fluent in reading. This is Sabari, the late comer in every situation. (Hirata, 2015: 32)

Sabari comes in the form of an innocent, honest, yet loving person. Sabari loves Marlena deeply and sincerely, though Marlena never expects his presence in her life. The more Sabari approaches, the farther away Lena goes away from him. Unfortunately, all the phenomenal achievements of Sabari make Lena even more brutal rejecting him. If formerly Lena simply does not reply Sabari's letters, now Lena is getting madder. She tears apart all Sabari's letter and throw them out to the parking lot to show that she really hates Sabari and wishes Sabari to be away from her life.

On the other hand, Sabar has got a superhuman endurance in matters of love. He never cares of what Lena has done to her. He acts as if nothing happens to him. Then he is also a hard worker and he never know the words 'give up'. He has a great self-confidence. The thing that is most reminiscent of Sabari is his true love. He really loves Lena under any circumstances, no matter how hard the situation is, his love towards Lena is never changed. Though Lena divorces Sabari, running away with Sabari's beloved child, and making Sabri almost mad, Sabari is consistent in his love towards Lena.

Marlena has a beautiful face with well-formed dimples. Marlena herself has a very different character from Sabari. She never wants to bother about everything. She wants things to be practical.

Lena's displeasing personality makes her easy to decide to divorce.

(Hirate, 2015: 234)

However, behind all her conducts, Marlena has got some positive personality traits. Marlena is a type of self-support person and she never relies on anyone. She has a firm mind, not easily influenced by any other person. Even her father could not influence the way of her thinking or life style.

Lifting the backdrop of the Belitung Island, the author uses the typical language styles featured in this novel. The fact that Andrea Hirata himself was born on the island of Belitung makes all the culture and atmosphere of Belitung penetrate easily in this novel Ayah. The rustic atmosphere of the 1990s in the novel keeps the readers bounced back to childhood. The lifestyle of the villagers bear lots of points of local wisdom manifested in the forms of moral values. (Widjaja, 2016)

Reading the novel Ayah makes the readers get some important and crucial life values, one of which is to respect and obey parents. Without parents, a person is only a nothingness. Besides there are two things that are not less important in life: hard work and self-confidence. These two moral values are the key to success in human life. Someone who is diligent and has strong self-confidence will always be able to solve any problem. These two moral values then become the focus of discussion in this study. 
Based on the things described above, there are several important reasons for choosing this novel as a base for a research. Andrea Hirata's novel Ayah is the product of modern Indonesian literature reflecting the life of modern society. The problems exposed in the novel reveal lots of the points of moral values and in terms of language styles the novel is easy to understand. By this it is necessary to do research on moral values contained in the novel Ayah: hard work and self-confidence.

\section{Literature Review}

The notion of moral values basically consists of the two generally independent concepts: "moral" and "value". Separately, they mean the set of particular social rules which have slightly different meanings in the society. However, they both deal with such categories as the positive and negative, the good and bad as well as the right and wrong. Taking these factors as a basis, people make their choices regarding their social life and relationships with others.

If we take the notion "value" separately, we will find out that it is a set of rules or concepts that have a particular meaning for a person or social group and make a contribution into some aspect of life. However, the notion of value is quite abstract and its sense can vary from person to person. When we are speaking about the term "moral", we need to indicate that it has a stronger social impact and a broader meaning than just "the good and bad", which means that morals are more precise in comparison to values. When we combine the two notions together, we will get a set of behavioral rules that have the absolute meaning for society or its representatives and play an essential role for decision making. (Harris, 2012)

One more facet is reviewing moral values as standards that rule person's behavior regarding the good and bad. Those standards may have various sources, such as religion, society, and laws. It should be mentioned that moral values correlate with such notions as society and law. What we mean is that the moral values can be the source for social rules and laws while law and society may play their part in shaping of moral values. When the moral rule takes its place in the social life, it becomes a value with time (in case it is respected and followed by individuals). Hence, the need for its official codification appears. This is how the process of a moral value turning into a law goes. (Peterson and Martin, 2015)

Moral values are the values defined by the society based on which a person's character is judged. A person is said to be good or bad on the basis of these values. A person's choices and decisions in life are dependent to a large extent on the moral values he/she bears. (Eylat and Tanaka, 2016)

Moral values define the norms of right and wrong and good and bad. These defined norms help the people understand as how they must act in the society in order to lead a peaceful life. Decision making becomes easy to some extent as a person knows the repercussions of his behaviour based on the moral principles he has been taught since childhood. 
Moral values give us an aim in life. We are grounded in reality and are motivated to do good for those around us if we bear good moral values. Helping others, caring for those around us, taking wise decisions and not hurting others are some of the examples of good moral values. These values help in bringing out the best in us. (Harris, 2012)

Moral values also derive from within one's own self. This is clearly demonstrated in the behavior of older infants and young toddlers. If a child has been forbidden to touch or take a certain object early on, they know enough to slowly look over their shoulder to see if they are being observed before touching said object. There is no need for this behavior to be taught; it is instinctive. Once, however, any form of discipline is applied to modify the child's behavior, the child now gains the capacity within himself to distinguish his right behavior from his wrong behavior. Now, the child can make correct choices based on his own knowledge. The choices that are made by an individual from childhood to adulthood are between forbidden and acceptable, kind or cruel, generous or selfish. A person may, under any given set of circumstances, decide to do what is forbidden. If this individual possesses moral values, going against them usually produces guilt. Various types of moral value are being discussed theoretically: honesty, hardwork, self-confidence, tolerance are some and each has its own base to be attended to. (Rachels, 2011).

Two of the moral values to be discussed in this research are hard work and selfconfidence. Hard work is the most important key to success. The achievements without hard work are impossible. An idle person can never gain anything if they sit and wait for the better opportunity to come. The person who is working hard is able to gain the success and happiness in life. Nothing is easy to be achieved in life without doing any hard work. (Tollander, 2011)

The constant vigilance and preparedness to work is the price we have to pay for the success in life. Work is a privilege and a pleasure, the idleness is a luxury that no one can afford. Man is born to work and prosper in life. He like steel shines in use and rusts in rest. The work is worship. The man of actions acts in the living present. There is no tomorrow for him. He makes the best of time. Life is full of strife. It is the action, activity of law of nature. A life of idleness is a life of shame and disgrace. Idle men are intruders on society. We are endowed with brain and limbs, which are meant to be properly exercised. The failure in life is very often due to idleness. The Industry is the key to success, Industry makes and idleness mars a nation.

Greatness can be achieved by great labour only. What a man earns by the sweat of his brow gives him a greater degree of satisfaction than what he gets by a stroke of fortune. The man wishes to have many things in their life. These latter things acquired by hard toil are much than those gets by accident. When a man earns by dint of toil; he enjoys a pleasurable sensation which is equivalent to the joy of having won a victory. Of this pleasurable sensation, the man who has been born with a silver spoon in his mouth knows nothing. A self-made man is certainly happier and more esteemed than the man who owes his fortune to the accident of his birth. (Smith, 2011) 
The next moral value is self-confidence. Self-confidence is freedom of doubt; belief in yourself and your abilities. Many people lack the self-confidence and self-esteem needed to live a happy and healthy life. Self-esteem is a confidence and satisfaction in oneself. These two things must be present in people's daily lives in order for them to believe that they have the ability to do anything. At this point in my life I am trying to gain the esteem I need to truly be happy. The best way to gain self-confidence is to look deep inside of yourself and believe that you have the ability to overcome all obstacles and challenges that you are faced with, on a daily bases, because our self-esteem is one of the few things that we have control over. (Albert, 2010)

Upon understanding what self-confidence is, it encompasses to know how a selfconfident person is. A self-confident person is an optimistic, loving, independent, assertive, eager, self-respect and self-control person, and believe and know well about own abilities. (Miller, 2013) Physically, a self-confident person looks confident with positive body language and good posture. That are, standing, sitting and walking with straight back, grasping hands in front or back of body, walking with wide steps, firm handshakes, making eye contact and smiling are signs of self-confidence.

\section{Research Method}

The method used is descriptive method. Creswell (2010) argues that research using descriptive methods means that data are broken down in the form of words or images, not in the form of numbers. Data are generally in the form of recordings, photographs, documents, memoranda, or other official records. In qualitative research reporting with careful verbal language is important because all interpretations and conclusions are taken verbally. This method is used to analyze the moral values in Andrea Hirata's novel Ayah.

The Sources of data for this research are taken from the novel Ayah by Andrea Hirata. The data are the texts of the quote associated with the moral values in the novel. Then, the instrument in this study is the researcher himself assisted by books and other respective references and on literature and educational values.

There are several stages for data collection techniques used in this study: reading stage, that is to read carefully the text with elements related to the moral values in the novel and books related to the discussions of the study; data marking stage related to moral values and recording and classifying the data found on moral values in the novel.

\section{Discussion}

Literary works are both entertaining and beneficial to the readers. Literature entertains by way of presenting beauty, giving meaning to life such as moral values, death, misery, and joy and being a means to convey the message of truth, about what is good and bad.

Literary works consist of various genres such as poetry, drama, and prose. One of the literary genres in the form of prose is novel. Novel as a work of fiction offers a world containing an idealized life model, , built through various intrinsic elements, such as 
events, plots, characterizations, backgrounds, or perspectives, all of which are of course imaginative. (Austin, 2013)

This novel tells about the life of Belitong Island people, about the struggle of a father for his son, also a child's struggle for his father. In it love a story is integrated, interspersed with various moral messages that can be used as a reference in everyday life. This novel is god for students as well as adults, because the values contained are appropriate to be a motivation for life. The moral messages in this novel are delivered in a beautiful way, through the distinctive language through which beautiful poems are implied.

The object of this study is the novel Ayah by Andrea Hirata (2015). Andrea Hirata is one of the authors to be reckoned with in Indonesian literature. The popularity of Andrea Hirata climbed after Laskar Pelangi was published. Andrea Hirata's works always get a good appreciation from the readers. Andrea Hirata also received many awards such as the winner of New York Book Festival 2013, General Fiction category, for Rainbow Troops (Laskar Pelangi, American edition), and the winner of Buchawards 2013, Germany, for Die Regenbogen Truppe (Laskar Pelangi, German edition) (Sutikno, 2016)

The novel Ayah is the work of Andrea Hirata published in May 2015. Not until a year, this novel has been reprinted up to ten times. This novel is also the first novel of Andrea Hirata which is not an autobiography and the first novel that is talking about education. The novel tells about the love of Sabari towards other figures. Sabari loves Lena very much, though Lena hates him. Sabari tries to get Lena's attention, until they get married. They get married, because of forced circumstances. Lena is pregnant out of wedlock and the biological father is not known until Sabari offers himself to marry her.

The novel Ayah, certainly consists of systematic elements among which occur mutual relationships. However, how each element influences another in the novel is not known with certainty. Therefore, the novel in the study is analyzed from a moral value point of view depicted from the major characters. There are two points of discussion in terms of moral values: hard work and self-confidence.

\section{Hard Work}

Success is about setting goals and achieving them. Such goals include losing weight, learning how to play an instrument, making profit in a business, and being the best in certain career among others. The secret of success, as many people will agree, is hard work.

Evidently, successful people are admired in the society. In many instances, they make headlines in the mainstream media. However, such people are not many in the society. Many people still struggle to achieve their goals in life. Others give up, all together, when they attempt without success to achieve their goals. Simply, many people are unable or unwilling to engage in hard work for them to be successful. 
In this study hard work is exposed by one of the major characters, that is Amiru. Although still small Amiru is used to working hard. Usually he works in rubber plantations, coffee and palm oil. This is illustrated in the following quotation.

Actually, Amiru is still a kid, but he has been used to hard work. In time of holidays, he will go to the plantation to get some extra work, as he knows that the money earned could be used to fill some of the important needs. Amiru seems to have great responsibility not only for himself but also for people around him. Hirata, 2015: 87)

Based on the above quotation, Amiru's attitude in working hard is seen through his seriousness in facing various obstacles to complete the task as well as possible. This is illustrated when he is doing a tough job, that is, when he is used to working in rubber, coffee or palm plantation. However, he thinks that such a work will make money slowly. So, he is looking for a tougher work which is quick to make money so he can catch up on the radio the schedule of which is getting closer. This is all done by Amiru for his father who loves to listen to radio broadcasts. From one side he is going to earn money quickly and from another one, he wants to please his father. As he is in the habit of working hard, he likes to seek a challenging work.

Another illustration of hard work is also shown by Zorro, a very tough boy in all cases. He does not wish to give up though various challenges may come to him and this is proved through the quotation below.

An intense trial makes Zorro a tough boy. He is much older than his age.

"What cannot kill you will make you stronger". This is his motto in his

life. And every time he feels inconvenient, he will take the shirt and kiss

it as that is a remembrance for him when there is an old man coming to him and hugs him and that event could not be wiped out from his mind.

(Hirata 2015: 269)

Based on the above quotation, it can be analyzed that Zorro has an attitude that does not give up easily in life. This is seen when the trials come in turns to him. What strikes him make him much stronger. His mind is much more mature than his age. This attitude is one example of a formidable attitude. Zorro is a boy who works without thinking of fatigue. He does not give up easily and he is not easy to say that he is tired because he says the word tired is the same as weakness.

\section{Self-confidence}

Self Confidence is the key to success, or the first step to success. If a person has self confidence, he has won half the battle. Those people who have self confidence at work, school, and in their daily life always appear on top of world. Everything seems to go right for these people and they always seem to present themselves as calm, collected and successful in everything they do.

Self-confidence is the belief in oneself and abilities, it describes an internal state made up of what we think and feel about ourselves. This state is changeable according to the situation we are currently in and our responses to events going on around us. It is not 
unusual to feel quite confident in some circumstances and less confident in others. It is also influenced by past events and how we remember them; recalling a former success has a very different outcome in terms of our confidence levels than thinking about an occasion when we failed.

In the study the attitude of self-confidence is shown by Sabari. Self-confidence is a selfassured attitude to have the courage and confidence in living a life consistent with wishes and expectations. When Sabari sees Lena's letter in a wall magazine, he is sure that the letter is for him. This is illustrated in the following quotation.

As he saw Lena's letter on the wall magazine on Thursday, Friday and Saturday he was sure that the letter was addressed to him. He did not go to school because of the shock of being too happy. He was sure that he would harvest love from the seed she had long sown to Lena. Hirata, 2015: 66)

Based on the above quotation, it can be analyzed that Sabari is confident of his own ability to fulfill every desire and expectation. This is seen when she sees Lena's letter to him on Thursday. He is convinced that on Monday he would harvest love from Marlena, his idol. This attitude is an attitude of confidence. He never thinks about things that could hinder a work. For him he can overcome all the obstacles only when he has confidence. He is always convinced that he would never have a problem with Lena. He loves Lena and he is convinced that Lena will also love him, very simply and that is a mind-set based on self-confidence.

The risk-taking attitude is also shared Sabari on another occasion. He wants to apologize to Lena and Bogel, because he has already blamed the cheat made by Bogel and Lena. This is illustrated in the following quotation.

'I want to ask for apology, to Bogel and Lena.' 'Yes'. 'To Bogel too, ...' 'Yea, ...' 'Ri, if you ask for apology to Lena, that is ok.... But to Bogel, you have to think twice, he is not a good person and he always mistreat you and he is always bad to you.'. 'No, Boi, this is my mistake and I have to do that, whatever the risk is. I am sure all will be done well'. (Hirata, 2015: 95)

Based on the above quotation, it can be analyzed that Sabari's readiness to accept the effects that may arise from the real action. This is illustrated when he wants to apologize to Lena and Bogel. Both friends have forbidden Sabari to ask forgiveness from Bogel because Bogel is always bad to Sabari. However, Sabari is ready to accept any risk, because he thinks that all is his mistake. And he dares to do that because he has a very strong confidence. The confidence that makes him strong like a castle and he is never afraid of anything.

\section{Conclusion}

Moral values are extremely important for overall well-being. Moral values provide a structure for life. Honesty makes people respectable. Compassion makes one sympathetic to others. Courage gives everyone the bravery to overcome life's 
challenges. Modesty keeps one focused and humble. Forgiveness allows one to be emotionally stable because one does not hold onto anger and resentment. These attributes will allow people to live their life in a way that reduces their stress levels. They will also have peace and harmony in life. Moral values allow one to live life in a manner that one can be proud of. The bonds that one forms with others will also be more fulfilling because one lives a life according to honesty, compassion, courage, modesty and forgiveness.

Based on the research results it is illustrated that there are two points of moral value in this novel. Both moral values are described by the major characters in the novel. The first moral value is hard work and pictured by Amiru and Zorro. These two figures do not easily give up in any difficulty because they have been accustomed to working hard. Hard work is the key to success. They do not recognize the term tired because for them the expression of tiredness is a weakness. The second point of moral value is selfconfidence and this moral value is described by Sabari. Basically Sabari is a key figure in this novel and he is a representative of moral values in accordance with all his actions and words. Sabari has extraordinary confidence. He believes Lena will love him and in every difficulty he always believes he can find a solution.

\section{References}

Albert, Jessica. (2010). Success or Failure. Chicago: Chicago University.

Austin, W., Wellek, R. (2013). Teori Kesusastraan Diindonesiakan Oleh Melani Budianto. Jakarta: Gramedia.

Creswell, John W. (2010). Research Design. New York: Sage

Eylat, Yael - Tanaka. (2016). The Book of Value. South Carolina: Publishing Platform.

Harris, Sam. (2012). The Moral Landscape: How Science Can Determine Human Values. New York: Free Press.

Hirata, Andrea. (2015). Ayah. Yogyakarta: Bentang.

Miller, Barbara. (2013). Character Power. New York: Random Inc.

Peterson, Christopher, and Martin E. P. Seligman. (2015). Character Strengths and Virtues. Oxford: Oxford University Press.

Rachels, et.al. (2011). The Elements of Moral Philosophy (7ed.). New York: McGraw-Hill.

Smith, Paul. (2011). Religion, Social Bonds, and Delinquency. Baltimore: Longman

Sutikno, Amin. (2016). Lebih Dekat dengan Andrea Hirata. Bandung: Pelita.

Tollander, Michael. (2011). Moral Values. Cambridge: University Press.

Widjaja, Priscilla Lee. (2016). Ulasan Novel Ayah Karya Andrea Hirata. Kompasiana. Retrieved from https://www.kompasiana.com/priscillaleew/ulasan-novel-ayahkarya-andrea-hirata 56d07ef8ae7a612b108b4571 on 12 February 2018. 